UDK 821.14'01.09Homer:78

78.032 .6

Jurij Snoj

Muzikološki inštitut Znanstvenoraziskovalnega centra

Slovenske akademije znanosti in umetnosti, Ljubljana

Institute of Musicology, Scientific Research Centre

of the Slovenian Academy of Sciences and Arts

\title{
Glasba v Homerjevi Iliadi
}

\section{Music in Homer's Iliad}

Ključne besede: antična grška glasba, antična epika, homerski aojd

\section{IZVLEČEK}

Številni glasbeni prizori v Iliadi so obravnavani s treh razičnih zornih kotov: (i) s stališča stvarne zvočnosti, kolikor je razvidna iz podanih opisov; (ii) s stališča družbene funkcije, ki jo ima glasba; (iii) s stališča estetskega jedra ter estetskih učinkov glasbe na homerske ljudi.
Keywords: ancient Greek music, ancient epic poetry, homeric aoidos

\section{ABSTRACT}

The numerous musical scenes in Iliad are approached from three different aspects: (i) to a limited extent they allow the technical description of the music played or sung; (ii) they are discussed from the viewpoint of the music's social function; (iii) they disclose the conception of music in the homeric world and its aesthetic impact on homeric people. 
Iliada in Odiseja, po starem izročilu pesnitvi slepega aojda Homerja, sta najstarejši grški literarni deli in kot taki že stoletja v središču zanimanja evropske humanistike. Kljub temu vprašanja njunega nastanka in avtorstva niso pojasnjena. Pesnitvi sta različni in po nekaterih razlagah je Homerjevo delo le Iliada, ki naj bi nastala v 8. stol., ne pa tudi nekoliko mlajša Odiseja, ki se v več pogledih, med drugim tudi v samem izrazju, loči od Iliade. ${ }^{1}$ Podobno ni rešeno vprašanje vloge, ki naj bi jo imel Homer oz. avtorja epa pri njunem nastanku. V splošnem prevladuje mnenje, da sta pesnitvi nastali na osnovi starejše, zgolj v ustnem izročilu obstoječe epike; Homer oz. avtorja obeh epov naj bi zbrala več do takrat le v ustnem izročilu obstajajočih epskih ciklov in jih združila v dva vsebinsko in oblikovno zaokrožena epa. ${ }^{2}$ Sklop vprašanj, znan kot homersko vprašanje, je zelo obsežen in zapleten; a ne oziraje se na različne možne odgovore ostaja dejstvo, da sta na začetku grške in s tem tudi evropske književnosti dve obsežni deli, ki ju je stari svet pojmoval kot neprekosljivi umetnini in vir vsega pesnjenja.

O čem govori Iliada? Mnenja o tem, ali so dogodki, opisani v epu, resnični ali ne, ali je Homer zanesljiv zgodovinski poročevalec, oz. kaj je zgodovinska osnova Homerjeve Iliade, so močno deljena. ${ }^{3}$ Homer govori o bojih pred maloazijsko Trojo, ki so jo skušali zavzeti Grki iz različnih delov matične dežele, združeni v eno vojsko pod vodstvom argoškega kralja Agamemnona, ki naj bi bil po drugem izročilu iz Miken. ${ }^{4}$ Starejša, predarhaična grška zgodovina se v zgodovinopisju deli na več obdobij. Obdobje mikenske kulture z jezikom, zapisanim v t.i. linearni pisavi B, ki zdaj velja za grščino, je imelo svoja vrhunca konec 16. in na začetku 14. stol. Obdobje se je končalo v 12. stol. z vdorom Dorcev na Peloponez, čeprav zatona mikenske kulture ni pripisovati zgolj pojavu Dorcev. Sledila je t.i. prehodna doba, doba temnih stoletij, imenovana tako zato, ker se je iz nje ohranilo le malo virov. V tem obdobju, ki je trajalo do 8. stol., so Grki, začenši ok. leta 1000, naseljevali Malo Azijo in se bojevali s tamkajšnjimi ljudstvi, kar bi mogla biti zgodovinska osnova za vsebino Homerjevega epa. ${ }^{5}$ Vendar so arheološka izkopavanja pokazala, da je bila Troja (plast VIIa) nasilno porušena že okoli leta $1200^{6}$ in tudi grški zgodovinarji so izračunali, da je bil padec Troje leta 1184 . $^{7}$ To pomeni, da bi mogli biti zavojevalci mesta ljudje mikenske kulture, in ne združeni Grki, ki so kolonizirali Malo Azijo šele v času od ok. leta 1000 dalje. Historičnost trojanske vojne, kot jo opisuje Homer, je vprašljiva.

Iliada ni besedilo, v katerem bi brez pridržkov iskali zgodovinsko resnico. Gotovo pa je besedilo, iz katerega veje določeni način življenja. Vsevedni pesnik v besedilu ne opisuje le tistega, kar sodi v glavni tok njegove pripovedi; vanjo skuša vplesti čim širši krog ljudi in dogodkov. Tako srečamo v epu veliko množico oseb z njihovimi lastnimi življenjskimi usodami: Homer pripoveduje, kje so bili doma, kdo so bili njihovi starši, s kom so bili poročeni, vse to pogosto sredi opisov bojev, ki so najpogostejša vsebina njegove pesnitve. Iz besedila vidimo, kaj homerski ljudje verjamejo in mislijo, česa se bojijo in česa se sramujejo. Poučimo se lahko o načinu bojevanja (zlasti mož proti možu) ter o mnogih drugih obrtnih dejavnostih in znanjih, kot so: izdelovanje orožja, tkanje, (VI, 456-, XXIII, 760-), umetnost lepotičenja (XIV, 170-), otroška igra (XV, 362-, XVI, 260-), tesanje ladij (XV, 410-), ribolov (XVI, 404-), vleka lesa iz gozda (XVII, 742-), ženski nakit (XVIII, 400-), zvezdoznanstvo (XVIII, 483-), navade ob porokah, pokopu (XXIV, 718-) itd. Poznavalci antike ugotavljajo, da se v Iliadi odražajo različne razvojne stopnje življenja: od najstarejše iz obdobja mikenske kulture do 8. stol., ${ }^{8}$ ko naj bi bil ep dokončno izoblikovan; s stališča literarnega bralca je vse, kar je v Iliadi, en sam značilen homerski svet.

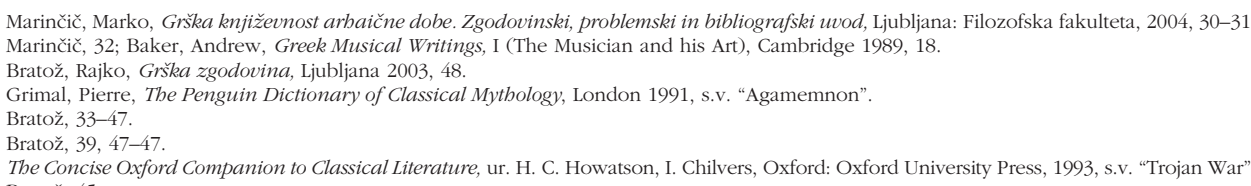


V širokem sklopu človeškega delovanja in čustvovanja, kot ga predstavlja Iliada, nastopa tudi glasba. Ljudje v homerskem svetu pogosto pojejo, igrajo, plešejo. Obstoj glasbe in plesa, kot se pojavljata v Iliadi, odpira tri sklope specifično glasbenih oz. glasbenozgodovinskih vprašanj. Prvič se zastavlja vprašanje homerske glasbene zvočnosti. Ali si je iz Homerjevih opisov mogoče ustvariti predstavo o tisti zvočnosti, ki si jo je homerska doba sama predstavljala kot glasbo? Kako natančni so opisi glasbe v Homerjevem pesniškem besedilu in koliko natančno je iz njih razvidno, kaj so poslušali homerski ljudje in kaj je v svoji pesniški predstavi slišal in opisal slepi aojd? Drugi sklop vprašanj zadeva mesto glasbe v homerskem svetu in hkrati s tem tudi vprašanje homerskih pesniško-glasbenih zvrsti. Glasba, petje, ples so vpeti v širše dogajanje: nastopajo v določenem dogajalnem okolju in ob določenih priložnostih. Tako se je mogoče spraševati o družbenem mestu glasbe in njenih nosilcev. Prav s funkcijo glasbe pa je povezano vprašanje zvrsti. Homerska glasba ni le eno; pesmi, ki jih pojejo homerski ljudje, imajo svojo vsebino, v zvezi z njo pa tudi določene glasbenooblikovne značilnosti. Te so v Homerjevih besedilih večkrat nakazane ali opisane, nekajkrat pa Homer tudi izrecno poimenuje pete pesmi, se pravi, da določi njihovo zvrstno pripadnost. Slednjič ima glasba v homerskem svetu določene estetske učinke, kar vodi k vprašanju, kako so jo homerski ljudje sprejemali, doživljali, in kaj so videli v njej. Da bi bilo mogoče odgovoriti na zastavljena vprašanja, je potrebno natančno pregledati vsa tista mesta v Iliadi, kjer se izrecno omenjajo ali opisujejo petje, igranje in ples (gl. tabelo, str. 64).?

\section{1}

Petje in igranje je v homerskem svetu vedno jasno ločeno od človeškega govora oz. drugih glasov in vedno razumljeno kot glasba. Kljub temu o sami zvočnosti homerske glasbe ni mogoče izvedeti veliko. Izrazi, največkrat pridevniki, s katerimi je opisana, se nanašajo bolj na estetski učinek, ki ga ima petje oz. igranje na poslušalca, kot pa na njegovo stvarno zvočnost. Še največ je o zvočnosti petja in glasbe mogoče izvedeti iz navedb, kdo poje in katero glasbilo igra. Če prisluhnemo homerskim glasbenim prizorom, slišimo: moško petje (npr. petje paiana); žensko petje (pojejo npr. Muze); petje moških aojdov, v katero se občasno mešajo glasovi žensk (tako v trenodiji); petje moških in žensk oz. petje ne natančneje določene skupine ljudi, ki ga spremljata glasbili avlos in forminga (petje himenaja); petje dečka, ki se spremlja na formingi, v katero posegajo drugi mladeniči in mladenke, se pravi moški in ženske (linos); petje enega samega moškega, ki se pri tem spremlja na formingi (Ahil); slišimo tudi sama glasbila: formingo (igra jo Apolon), sirinkse (pastirji), salpinks, sirinkse skupaj z avlosi (v trojanskem taboru). Kakšna je bila glasba, ki jo je v svoji predstavi slišal Homer: intervalno artikulirana ali ne, enoglasna ali večglasna, melizmatska ali silabična, v velikem ali majhnem obsegu, o vsem tem iz njegovega pesniškega besedila ni mogoče izvedeti veliko. Nekateri opisi nakazujejo heterofonijo: sočasno igranje sirinksov in avlosov v trojanskem taboru; prizor s pastirjema, ki istočasno piskata na svoja sirinksa; petje himenaja, ki ga spremljata avlos in forminga; vzklikanje mladeničev in mladenk, ki skupaj z dečkom pojejo linos; prav tako se nakazuje heterofonija v stokanju žensk v zaključni trenodiji. Slednja dva prizora (linos in trenodija) dopuščata predstavo, da so bili vzkliki mladeničev in mladenk ter stokanje žensk z glasbenega stališča intervalno bolj ali manj neartikulirani melizmi.

Po splošno sprejeti predstavi je bila antična glasba enoglasna. Stari svet si glasbe ni predstavljal kot kombiniranje sočasno zvenečih intervalov ali dveh različnih, vendar medsebojno usklajenih melodij. Glasbila so spremljala pevca tako, da so podvajala melodijo njegovega petja, morda $\mathrm{v}$ smislu heterofonije, se pravi v nekoliko drugačni enačici. Aojdu, ki je držal v rokah formingo,

9 Uporabljeni sta bili izdaji: Homer, Iliad, prev. A. T. Murray, William F. Wyatt, Loeb Classical Library, 170, 171, Cambridge (Massachusetts), London, Harvard University Press: 1999; Homer, Iliada, prev. Anton Sovre, Ljubljana 1950. 
so toni le-te služili kot opora njegovega petja. Mestoma je v premoru mogel zabrenkati ton ali dva, ki sta predstavljala kratek mostič med dvema frazama njegovega petja. Kot enoglasno ali heterofono si moremo predstavljati tudi homersko petje. To pomeni, da sta obseg ter tonski sestav homerskega petja do določene mere predstavljiva na osnovi vedenja o antičnih in homerskih glasbilih.

V Iliadi se omenja pet glasbil: brenkali forminga in kitharis, pihali avlos in sirinks ter trobilo salpinks. ${ }^{10}$ Forminga in kitharis sodita v družino lir, ki vključuje liro v ožjem smislu (chelys), barbitos, formingo in kitharis. Izraz kítharis je kasneje zamenjal izraz kithára. Raba navedenih izrazov v grški literaturi ni bila povsem ustaljena, saj so se bolj kot za čisto določena glasbila poljubno uporabljali za katero koli glasbilo iz družine lir. V starejših besedilih sta pogostejša izraza forminga in kitharis, ki so se jima v času od 6. stol. dalje pridružili še izrazi lira, chelys, barbitos, kithara. Kljub pogosti nejasnosti je na osnovi ikonografskih virov za navedenimi izrazi vendarle možno prepoznati štiri različne tipe lir. ${ }^{11}$ Za razliko od lire (v ožjem pomenu besede), ki je imela za resnonančo dno želvin oklep, za kraka pa živalska rogova, je bila forminga leseno glasbilo: na resonančni, spodaj konkavno zaobleni trup sta bila pritrjena dva kraka, tudi lesena, ki sta bila verjetno votla in sta zato tudi sama delovala kot resonančni trup. Kraka sta bili zgoraj povezana s prečko (zygon). Strune so bile napete od zgornje prečke (zygon) preko kobilice, ki je slonela na resonančnem trupu, na držalo ob spodnjem delu resonančnega trupa. ${ }^{12}$ Podobno sestavo je imela tudi kitharis oz. kithara, glasbilo kasnejših profesionalnih kitarodov.

Ni gotovo, da Homer ločuje med formingo in kitharis, in možno je, da zaznamuje z obema izrazoma isto glasbilo. ${ }^{13}$ Zelo verjetno sta homerska forminga in kitharis glasbilo z lesenim trupom, in ne chelys iz želvjega oklepa. ${ }^{14}$ Že v homerskem Himnusu Merkurju ima lira, sicer ne imenovana tako, sedem strun, in stari svet je pripisoval povečanje števila strun na sedem Terpandru z Lesbosa, ki naj bi živel v 7. stol. ${ }^{15}$ To izročilo se ujema z ikonografsko evidenco. Upodobitev forminge (glasbila z lesenim trupom) iz 11. stol. ter redke upodobitve istega glasbila iz 9. stol. ga kažejo $s$ tremi ali štirimi strunami. Tri ali štiri strune ima to glasbilo tudi na več deset upodobitvah iz 8. in zgodnjega 7. stol.; drugače je le na nekaj upodobitvah 8. stol., kjer ima forminga več kot štiri strune: pet, šest, sedem. ${ }^{16}$ Iz tega je mogoče sklepati, da je imelo glasbilo, ki ga omenja Homer, homerska forminga, zelo verjetno le tri ali štiri strune. O njihovi uglasitvi, kot o uglasitvi antičnih strunskih glasbil sploh, je možno le ugibati in strogo vzeto ni znana. ${ }^{17}$ Iz teoretičnega spisja izhaja, da je bil urejevalni princip uglasitve na sedmerostrunih glasbilih tetrakord in strune naj bi bile na njih uglašene v smislu osrednje oktave velikega popolnega sistema. ${ }^{18}$ Tudi za homerska glasbila se domneva, da so bile njihove tri ali štiri strune uglašene v obsegu čiste kvarte, vendar so vse rekonstruirane uglasitve zgolj hipoteze.

Z domnevno uglasitvijo homerske forminge je mogoče primerjati uglasitve antičnega avlosa, ki je v Iliadi omenjen dvakrat. Avlos je bil najbolj razširjeno grško pihalo. Čeprav je izraz za glasbilo po izvoru grški (s pomenom 'cev'), glasbilo samo najbrž ni bilo grškega izvora, saj so upodobitve parov piščali, domnevno avlosov, starejše. ${ }^{19}$ Osrednji del avlosa je bila cev iz trsta, lesa

10 Grški samostalnik ženskega spola "forminx" se je v slovenščini že udomačil kot 'forminga' (gl. SSKJ); ker sta "salpinX" in "syrinx" samostalnika iste sklanjatve kot "forminx", bi ju bilo mogoče sloveniti kot 'salpinga' in 'siringa', vendar je za slednje glasbilo izraz 'sirinks' (gl. SSKJ) že preveč uveljavljen, da bi ga bilo smiselno menjati. Problematičen je ustrezni slovenski izraz za antično kitharis oz. kitharo ("kithára"). Najprimernejši bi bil izraz kitara, ki izhaja iz pravkar navedenega grškega samostalnika; vendar je izraz tako močno povezana z novodobnim, od grške kitharis povsem drugačnim šeststrunskim brenkalom, da se zdi smiselneje uporabljati izraza kítharis in kithára.

11 Mathiesen, Thomas J., Apollo's Lyre, University of Nebraska Press, 1999, 235-236.

12 Mathiesen, 255-257.

13 West, Martin Litchfield, Ancient Greek Music, Oxford: Clarendon Press, 1992, 50.

14 West, 50.

15 West, 330.

16 West, 51-52.

17 Mathiesen, 237.

18 Mathiesen, 243-246.

19 West, 82. 
ali kosti, ki je imela največkrat cilindrično in le redko konično obliko. V gornji konec cevi sta bila drugi v drugega vstavljena dva rahlo zaobljena valja, in v zadnjega je bil nameščen ustnik z jezičkom. ${ }^{20}$ Noben antični ustnik se ni ohranil in tako ni gotovo, ali je bil avlos glasbilo z dvojnim (kot oboa) ali enojnim (kot klarinet) jezičkom. ${ }^{21}$ Zdi se, da je bilo z vstavljanjem ali opuščanjem enega od obeh valjev mogoče podaljšati oz. skrajšati cev in spremeniti s tem lego tonov in intervalna razmerja med njimi. ${ }^{22}$ Avlos je imel največkrat pet luknjic na zgornjem delu in eno za palec na spodnjem delu resonančne cevi. Iz ohranjenih avlosov je težko določiti njihove uglasitve, saj so toliko nepopolni, da ni mogoče določiti razdalje od jezička (kjer se proizvaja zvok) do prve luknjice. Kljub temu se zdi najverjetneje, da sta bila drugi in peti ton avlosa v razmerju čiste kvarte; intervala znotraj kvarte sta bila domnevno večja od poltona in manjša od celega tona; podobno sta bila tudi intervala nad in pod čisto kvarto domnevno manjša od celega tona. ${ }^{23} \mathrm{Zdi}$ se, da prepihovanje ni bilo sestavni del igralne tehnike, pač pa le sredstvo za posebne učinke, med drugim tudi v Pitijskem nomosu. ${ }^{24}$ Avlos je bil tako malotonsko glasbilo s šestimi toni, od katerih so bili notranji štirje v obsegu čiste kvarte. Igralci na avlos so skoraj vedno upodobljeni tako, da imajo v ustih dve glasbili hkrati, in tako je tudi na najstarejših upodobitvah avlosa. Iz ohranjenih upodobitev je razvidno, da sta bili sočasno igrani glasbili bolj ali manj enaki in da sta imeli enako razporejene luknjice; to nakazuje možnost, da je igralec igral v istem registru, zelo verjetno eno samo melodijo. ${ }^{25}$

Naslednje homersko glasbilo, sirinks, je v Iliadi omenjeno dvakrat. Izraz je lahko zaznamoval eno samo brezjezično piščal, narejeno iz votlega stebla, ali pa skupino povezanih piščali različnih dolžin in različnih uglasitev, se pravi glasbilo, znano kot panova piščal. ${ }^{26}$ Homer navaja obakrat množino, vendar to še ne dokazuje, da je imel v mislih skupino piščali oz. panovo piščal, saj se njegova množina nanaša lahko na sočasno oglašanje dveh posamičnih piščali. To še zlasti velja za opis zvokov v trojanskem taboru, kjer se glasovi sirinksov mešajo z glasovi avlosov. Piščali sirinksa so imele lahko različne uglasitve. V kasnejšem, morda že srednjeveškem opisu glasbila se dolžine piščali postopno, vendar enakomerno manjšajo; najdaljša bi glede na podane mere mogla meriti ok. $20 \mathrm{~cm}$, njej sosednja $18 \mathrm{~cm}$, naslednja $16 \mathrm{~cm}$ itd.; to pomeni, da bi mogel biti interval med prvima dvema tonoma vzpenjajoče se lestvice nekaj manjši od celega tona; drugi bi mogel biti celi ton (razmerje 9:8), tretji nekoliko večji kot celi ton itd. ${ }^{27}$

Četrto glasbilo, ki nam omogoča oblikovanje predstave o homerski zvočnosti, je trobilo salpinks, omenjeno v Iliadi le enkrat. Salpinks je bil bronasta ali železna cev. Na enem koncu je imel roževinast ustnik, ki se je vstavljal v cev, na drugem pa zvonast odmevnik (v grščini 'zvon'). Tudi ta je bil samostojen in se je vstavljal ali izstavljal iz cevi. Salpinks je bil tako dolg, da ga je mogel tik pred odmevnikom igralec podpirati z desnico. Kot avlos se je tudi salpinks igral tako, da je imel igralec prek ust in lic privezan trak, ki mu je pri pihanju stiskal lica. Salpinks ni imel možnosti daljšanja ali krajšanja cevi, tako da so se nanj mogli igrati le toni alikvotne vrste. Dolžino cevi je bilo do določene mere mogoče podaljšati ali skrajšati le z menjavo ustnika. ${ }^{28}$ Najstarejša upodobitev salpinska je šele s konca 6. stol., se pravi iz dve stoletji mlajšega časa kot homerski epi. ${ }^{29}$ Edini ohranjeni salpinks ustreza podanemu opisu in meri ok. $157 \mathrm{~cm} .{ }^{30} \mathrm{~V}$ 5. stol. naj bi se v Bo-

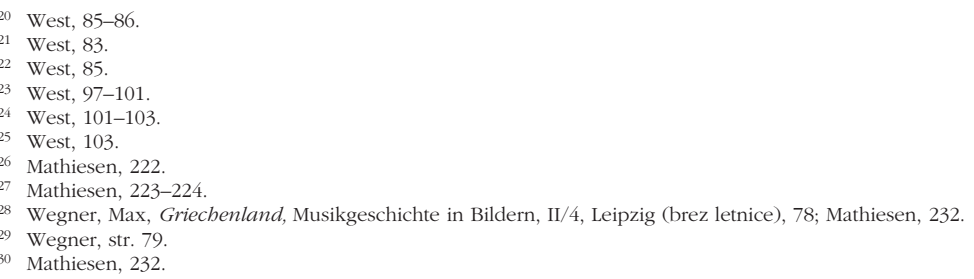


jotiji prirejali agoni salpinksistov, a zdi se, da je bilo pri teh agonih bolj kot tehnika igranja ali glasba v ospredju izkazovanje moči, s katero naj bi igralec proizvedel kar najmočnejši ton. ${ }^{31}$

Salpinks je bil skoraj izključno vojaško glasbilo in z njim so se v bitki posredovala sporočila ali ukazi. Govorjeni ukazi se sredi hrupa orožja in kričanja ljudi ne bi razločili, poleg tega bi jih mogla razumeti tudi sovražna stran. Nasprotno pa je bil salpinks s svojim prodirnim glasom dobro razpoznaven in različna zaporedja tonov so mogla delovati kot dogovorjeni znaki za medsebojno sporazumevanje ali kot sporočila ukazov. Poleg tega je bil namen salpinska tudi vzbujanje strahu. ${ }^{32} \mathrm{~S}$ prodornim, kar se le da močnim tonom ali neartikuliranim trobljajem naj bi glas salpinksa na začetku bitke v sovražniku vzbudil grozo.

Na osnovi domnevnih uglasitev si je z ozirom na to, da je bila antična glasba enoglasna, mogoče ustvariti približno predstavo o tonski podobi homerskega petja oz. glasbe. Ker so imela antična glasbila majhno število tonov, je potekala homerska glasba domnevno v ozkem obsegu. Ta je zelo verjetno vključeval čisto kvarto, ki je predstavljala stabilni interval. Ostali toni oz. intervali, bodisi znotraj kvarte bodisi zunaj nje, so bili v splošnem bolj labilni. To se sklada z anatomijo kasnejšega tetrakorda kot najmanjšega tonskega sistema antične harmonične teorije. Uglasitve posamičnih glasbil, ki bi mogle biti podobne opisanim, si je mogoče predstavljati kot lestvice dejansko petih melodij in verjetno so bile nekatere uglasitve oz. lestvice v homerskem času že ustaljene. Vendar pa Homer, ki naj bi bil sam aojd, pojmov kot lestvica, uglasitev, harmonija, ne pozna.

\section{2}

Bolj kot zvočna podoba je iz besedila Iliade razvidna vloga, ki jo ima glasba v homerskem svetu. Iz vrste prizorov in dogodkov, ki vključujejo petje, igranje, ples, je razvidno, da se je ob različnih priložnostih pojavljala različna glasba, kar pomeni, da pozna homerski svet razmeroma izrazite glasbene in pesniško-glasbene zvrsti. Svet Iliade ne pozna pismenosti; ${ }^{33}$ poje in igra se le iz spomina. A prav zaradi tega je glasba toliko bolj spojena z dogodki, v katerih nastopi.

Če začnemo pregled z glasbo samih glasbil, najdemo v Iliadi igranje na formingo ali kitharis, se pravi kasnejšo kitaristiko, zvoke sirinksa, salpinksa, ter skupno oglašanje avlosov in sirinksov. Prvič srečamo formingo ob koncu prvega speva, v glasbenem prizoru na Olimpu (I, 601-604): Zevs je privolil Ahilovi materi Tetidi, da bo na trojanski strani, dokler se Grki ne oddolžijo Ahilu. Hera, Zeusova žena, je uganila vsebino pogovora, ki sta ga imela Tetida in njen mož, ter se zaradi Zeusove namere z njim sporeče. Bogovi so vznemirjeni zaradi spora. Izgladi ga Herin sin Hefajst, šepavi olimpski umetnik, ki ob koncu svojega nastopa pove, kako ga je Zevs nekoč pahnil z Olimpa, da je padel na otok Lemnos, zaradi česar je ostal šepav. Hefajst nato toči bogovom nektarja in bogovi se smejejo njegovi šepavi hoji. Cel dan traja gostija in ničesar ne manjka: niti ne manjka prelepa forminga, ki jo igra Apolon, niti ne manjkajo Muze, ki izmenjaje se pojejo z lepim glasom. Iz Homerjevega opisa ni razvidno, ali se Muze izmenjujejo druga z drugo ali pa se izmenjujejo z Apolonom, oz. ali Apolon le spremlja Muze ali igra sam. Vendar je Apolon kot igralec na formingo prikazan še enkrat (XXIV, 62-63): Hera se spominja poroke Ahilovih staršev, boginje Tetide in Peleusa. Vsi bogovi so bili na svatbi; med njimi je bil tudi Apolon, ki je imel v rokah formingo.

Dejstvo, da poslušajo bogovi v Iliadi le Apolonovo formingo, priča o visokem statusu, ki ga je imelo glasbilo. Ta je nedvomno povezan s tem, da sta bili forminga in kitharis glasbili homer-

31 Wegner, 78

32 Mathiesen, 230-231.

33 Edina izjema so "pogubni znaki", ki jih je Belerofont nesel s sabo v Likijo, ne da bi vedel, kaj nosi. Njegov gostitelj je iz znakov razbral, da mora biti Belerofont pogubljen (VI, 167-). Odlomek je napisan tako, kot da tudi avtor besedila ne bi vedel, kaj so ti znaki. 
skih aojdov. V Iliadi nastopa poimensko le en aojd, Thamyris. V t.i. katalogu ladij v drugem spevu so med mnogimi udeleženci vojne omenjeni tudi vojščaki iz Pylosa in okoliških krajev, ki so pod vodstvom starega Nestorja prispeli pred Trojo z devetdesetimi ladjami. Ko Homer med kraji, od koder so prišli, omeni Dorion, ga zanese stran od naštevanja (II, 601-604). Tu so namreč Muze srečale aojda Thamyrisa. Ker se je bahal, da bo prekosil celo Muze, so ga kaznovale: ohromile so ga, odvzele so mu petje in naredile so, da je pozabil umetnost igranja na kitharis. Iz Homerjeve ubeseditve se zdi, da se je Thamyris odpravljal na muzični agon, katerega obstoj je nakazan sicer le na tem mestu epa.

Homerska forminga je tudi glasbilo plesa. V enem od glasbenih prizorov na Ahilovem ščitu je upodobljeno plesišče (XVIII, 590-606), takšno, pravi pesnik, kot ga je Dedal v Knososu zgradil za Ariadno. Na njem so plešoči mladeniči in mladenke; sredi med njimi sta dva, ki vodita ples; gibanje plesalcev je opisano na način, ki dopušča misel o načrtovani koreografiji; okoli stojijo gledalci; med njimi je aojd, ki igra na formingo. Plesno gibanje izhaja iz njegove glasbe. Samo igranje na strunsko glasbilo je še nekajkrat omenjeno: Ko se Hektor huduje na Parisa, ki se ne udeležuje bojev, ga pozove, naj se pomeri z Menelaom, ki mu je odvedel ženo; če se bo z njim spopadel, mu kitharis ne bo koristila, kot tudi ne darovi Afrodite (III, 392-394). K sliki lepega Parisa očitno spada tudi to, da igra kitharis. Podobno je mimogrede omenjeno igranje na kitharis, ko skuša sredi bitke Polydamas pregovoriti vojskujočega se Hektorja, da bi bilo pametneje, ko bi se Trojanci začasno umaknili. Opomni ga, da niso vsi ljudje zmožni vsega; nekomu je bog podelil zmožnost bojevanja, drugemu ples, zopet drugemu kitharis in pesem (XIII, 731). Tako naj tudi Hektor ne posluša le samega sebe, ampak tudi druge. Iz predstavljenih opisov, čeprav so kratki, izhaja, da je Homerski svet poznal samo igranje na formingo ali kitharis in da je imelo to igranje svoje družbeno mesto: bilo je sestavni del družabnosti, gostije, bilo je izhodišče plesnega gibanja; poleg tega nakazuje omemba Parisovega igranja možnost, da bi moglo biti tudi povsem zasebno početje.

Določeno vlogo ima tudi sirinks, ki je v Iliadi omenjen dvakrat. Homer, ekstravagantni pesnik, išče nenavadne načine pripovedovanja. Grških junakov ne predstavi neposredno, pač pa prek t.i. "opazovanja z obzidja«: Trojanci s svojega obzidja gledajo grško vojsko in sprašujejo Heleno, ugrabljeno Grkinjo, kdo je kateri od njih. Helena odgovarja in tako poslušalec (bralec) spoznava grške junake preko oči in ust lepe Helene, vzroka vojne. Podobno je z Ahilovim ščitom, ki ga glavnemu junaku epa izdela umetnik med bogovi, Hefajst. Hefajst upodobi na ščitu celo vrsto prizorov in zgodb in zanimivo je, da so med temi kar štirje takšni, ki vključujejo glasbo. Med drugim nastopi glasba v opisu drugega od obeh mest, "mesta v vojni", ki je bolj kot opis zgodba, za katero si je težko predstavljati, kako bi jo bilo mogoče podati z eno samo sliko: Meščani mesta, ki ga oblegajo sovražniki, razpostavijo na zidovje ženske in otroke, sami pa se umaknejo k reki, kjer nameravajo pripraviti zasedo. Čakajo, da pridejo pastirji s čredami živine. Res se prikažeta dva, in ta dva piskata na sirinks (XVIII, 525-526). Meščani napadejo čredo, jo zajamejo, ubijejo pastirja. Ko oblegovalci zaslišijo hrup, pridejo na mesto, kjer čakajo v zasedi meščani, in vname se bitka. Tu se prizor konča. Še pred tem je v Iliadi sirinks omenjen skupaj z avlosom. Na večer dneva, ko se poslanci, ki so skušali pregovoriti Ahila, naj se vrne v boj, vrnejo praznih rok, Agamemnon ne more spati in zaskrbljeno vzdihuje. Gleda proti Troji in se čudi: na trojanski strani vidi ognje, sliši človeški hrup, ki se meša z zvoki sirinksov in avlosov (obakrat množina; X, 11-13). Trojanci očitno niso utrujeni, pač pa se zabavajo in k zabavi sodi tudi oglašanje piskal. Zdi se, da Homer, zdaj v vlogi Agamemnona, kot poslušalec ne sliši ene same razločne melodije. Bolj kot to nakazujejo njegove ubeseditve, da sliši značilni, prepoznavni in sprepletajoči se zvok različnih piskal. Očitno je bil sirinks že v homerskem svetu glasbilo preprostih ljudi in pastirjev. Dolga zgodovina pastoralne glasbe ima svojo prvo literarno upodobitev na Ahilovem ščitu.

Salpinks je v besedilu omenjen le enkrat (XVIII, 219-221), vendar na nespregledljivo razpoznaven in značilen način; poleg tega se pojavi glas salpinksa na pomembnem prelomnem me- 
stu epa. Ko Trojanci in Grki bijejo boj za Patroklovo truplo, pošlje Hera poslanko Iris k Ahilu z naročilom, naj se tudi on odpravi v bitko. Ahil, ki se zaradi svoje jeze na ostale Grke še vedno vzdržuje boja, se brani, saj je svojo bojno opravo dal zdaj mrtvemu Patroklu in je tako brez nje. Iris mu odgovori, naj se samo pokaže Trojancem, saj jih bo ustrahovalo že to, da ga vidijo. Ahil se ukloni; odpravi se proti Trojancem in se pokaže na zidu. Njegova podoba je strašna; obdan je z božanskim gorečim sijem, ki mu ga daje nevidno spremljajoča ga jasnookoa boginja Atena. Spusti se proti jarku in tam trikrat zarjove. Ahilova ožarjena podoba ter njegovi kriki vzbudijo nepopisno grozo; ne le ljudje, tudi konji slutijo pogubo in se preplašijo. Vendar je vsevednemu pesniku, ki gleda in tudi sliši prizor, premalo, da bi povedal le to, da Ahil rjove. Da bi v bralcu vzbudil pravo predstavo krika, zlasti pa njegovega groznega učinka, pove s primero: Ahil zakriči tako, kot bi zavrisnil salpinks. Oglašanje salpinksa ima v homerskem svetu jasno vlogo: glas salpinska je glasba vojne.

Če se od oglašanja glasbil samih usmerimo k petju, moramo na prvem mestu omeniti tisto, kar Iliada sama je: epska pripoved, ki si jo je homerski svet predstavljal v glasbeni podobi. Da je epsko pesništvo v Homerjevi predstavi glasba, pove že prvi stavek Iliade (I, 1), v katerem se pesnik obrne na boginjo (Muzo): ta naj poje o Ahilovem gnevu. To pomeni, da naj boginja, prek nje pa Homer, pripoveduje zgodbo prek petja. Še na nekaj mestih je izrecno omenjeno peto podajanje epske pripovedi. V prizoru, kjer se srečajo Paris, Helena in Hektor, slednji spodbuja Parisa, naj se udeleži bojev, ki se jim izmika, saj je vojna pravzaprav zaradi njega. Helena se zamisli nad svojo usodo: Zevs jim pošilja le slabo; prav zato pa bodo prihodnji rodovi peli o njih (VI, 358). V Homerjevi predstavi bodo torej prihodnji rodovi pripovedovali o slavnih dogodkih pred Trojo tako, da bodo prepevali. Peto pripovedovanje je nakazano tudi v prizoru, ko pride grško poslanstvo k Ahilu, z namenom, da bi ga prepričalo, naj ne bo več užaljen, pač pa naj se zopet udeležuje bojev. Ahil, ki ne dela nič, je pri svojih ladjah. Dušo si lajša s formingo; ta je posebno lepo izdelana in ima srebrno prečko; glasbilo si je odbral iz plena, ko je uničil mesto Eetion. Z glasbilom si razveseljuje svojo notranjost; ob tem poje, in sicer o slavnih dejanjih mož (IX, 189). S tem je očitno mišljeno nekaj, kar je blizu epskemu pripovedništvu.

Aojd, ki je prepeval epske pesnitve, je po hipotezah sodobnih poznavalcev iz verza v verz ponavljal isto melodično formulo, ki jo je malenkostno prilagajal prozodični in metrični obliki vsakega heksametra. Ponavljajoči se glasbeni obrazec je mestoma menjal, s čimer je mogel stopnjevati učinek svojega podajanja. Forminga mu je služila za oporo, vendar je na začetku svojega podajanja v smislu uvoda, ali pa med verzi v smislu prehoda lahko zaigral tudi nekaj samostojnih tonov. Hipotetično bi mogli biti toni njegovih glasbenih obrazcev v razmerju a, h, c', e', s težiščem na tonu h, se pravi kvarta h-e', zapolnjena z enim tonom znotraj svojega obsega in ražsirjena z enim tonom navzdol. ${ }^{34}$

Poleg pete epike, za katero Homer nima posebnega izraza, so v Iliadi izrecno opisane in imenovane še štiri zvrsti: himenaj, linos, paian in tren. Prvi od mnogih prizorov, ki jih je Hefajst upodobil na Ahilovem ščitu, predstavlja "mesto v miru«: Obhaja se svatba; ob gorečih baklah vodijo neveste skozi mesto; poje se himenaj; mladeniči se vrtijo v plesu; slišijo se zvoki avlosov in forming (obakrat množina); ženske stojijo vsaka ob svojih vratih in z občudovanjem gledajo prizor (XVIII, 491-496). Iz Homerjevega besedila ni razvidno, ali je treba himenaj ločiti od plesa ali pa je vse skupaj en sam glasbeni prizor: petje himenaja, ki ga spremljajo glasbila ter ples mladeničev. Kasnejši pesniki opisujejo podobne prizore ${ }^{35}$ in iz 6. stol. je ohranjena tudi upodobitev sprevoda nevest. ${ }^{36}$ Etimologija izraza himenaj ni pojasnjena. Himenaj, po katerem naj bi se imenovala zvrst, je figura iz grške mitologije, o kateri obstoji več različnih izročil. Po enem naj bi bil bog;

\footnotetext{
West, 128,328

35 West, 21-22.

36 Mathiesen, 127-128.
} 
po drugem muzik, ki je igral na poroki Dioniza in Althaee; po tretjem naj bi bil nekdo, ki je umrl na svoj poročni dan. Po nekem drugem izročilu naj bi bil zopet mladenič, ki je bil tako lep, da je izgledal kot dekle; zaljubil se je v neko Atenko, vendar je bil prenizkega rodu zanjo. Nekoč so pirati ugrabili atenske mladenke in njega, misleč da je dekle. Ko so pospali, jih je Himenaj pobil in privedel mladenke nazaj $\mathrm{v}$ Atene. V zahvalo je dobil svojo izvoljenko in se z njo poročil. ${ }^{37}$ Po nemitološki razlagi je izraz himenaj izpeljan iz eolskega glagola za "živeti skupaj v slogi“. ${ }^{38}$ Misel na Himenaja je bila vsesplošno prisotna na porokah in kasnejši ohranjeni himenaji vključujejo klic temu božanstvu. Med drugim ga najdemo tudi v Katulovem himenaju (Katul, 61), kjer se ponavlja refren "o Hymenaee Hymen, o Hymen Hymenaee". V Aristofanovi igri Mir ima himenaj takšno obliko, da se izmenjujejo sam ženin, dve zborski skupini ter celotni zbor. ${ }^{39}$ Iliada ne omenja niti klica niti ni iz besedila mogoče razbrati, da bi bilo pri petju udeleženih več skupin. Homerski himenaj je tako mogoče določiti le kot zborovsko pesem, spremljano z glasbili in plesom ter čisto določeno funkcijo: kot pesem, ki se poje v sprevodu nevest, ki odhajajo na nove domove.

Nadalje je Hefajst na Ahilovem ščitu upodobil trgatev: Mladeniči in mladenke nosijo sladko grozdje iz vinograda; v njihovi sredi je deček, ki milo poje linos in se spremlja pri tem na formingi. Mladeniči in mladenke udarjajo z nogo ob tla, plešejo in vriskajo (XVIII, 569-572). Linos se imenuje tako po mitološkem Linosu; bil naj bi torej "Linosova pesem". Linos sam je bil muzik in o njem govori med drugim tudi eno od fragmentarnih, Nikomahu iz Gerase (1.-2. stol.) pripisanih besedil, ki opisuje kronologijo igranja na liro: Iznašel jo je Hermes, ki je umetnost igranja na glasbilo predal Orfeju; Orfej je naučil igrati liro Thamyrisa (aojda iz II. speva Iliade) in Linosa in slednji Amfiona ter Heraklesa. ${ }^{40}$ Ker se linos pri Homerju pojavi v prizoru ob trgatvi, se označuje kot delovna trgatvena pesem. ${ }^{41}$ Antični komentator Homerja navaja nekoliko drugače: linos naj bi bil žalostinka, ki se poje s posebnim, tanko-šibkim glasom. Ta oznaka izhaja verjetno iz pridevnika, s katerim je Homer označil glas dečka, ki poje linos. Sicer je znano, da so bile v starem svetu razširjene pesmi, kjer sta se izmenjavala solist in zbor, in še posebej so bile takšne trgatvene pesmi. ${ }^{42}$ Možno je, da se Homerjev pesniški opis nanaša prav na petje tovrstne trgatvene pesmi, pri katerih se izmenjujeta pevec in zbor. Iz Homerjevega opisa si ni mogoče misliti, da bi bil linos žalostinka.

Dvakrat je v Iliadi omenjen paian. Potem ko Grki vrnejo Hriseido, jabolko spora med Agamemnonom in Ahilom, njenemu očetu, Apolonovemu duhovniku, darujejo spravno daritev Apolonu. Koljejo in žgejo živali, potem se gostijo z mesom. Ko se najejo in napijejo, cel dan s pesmijo mirijo užaljenega boga; lepo pojejo paian; opevajo boga, ki deluje od daleč (I, 472-474). Drugi paian ima drugačno vlogo. Ko Ahil slednjič ubije najpomembnejšega trojanskega bojevnika Hektorja, mu sname opravo in nagovori svoje vojake. Spomni se, da ob grških ladjah leži ubiti Patroklos, njegov najdražji prijatelj, ki ga niti v Hadu ne bo pozabil. Za tem pozove tovariše: pojoč paian naj bi skupaj odšli k ladjam in odvlekli tja Hektorjevo truplo (XXII, 391). Paian je težko določljiva zvrst, saj je mogel biti le kratek vzklik božanstvu Paian, ki se največkrat enači z Apolonom, ali pa dolga pesnitev; pel ga je zbor ali en sam pevec, z glasbili ali brez njih; bil je predvsem kultna pesem, vendar se je pel tudi ob številnih drugih priložnostih in pogosto so ga bojevniki peli pred bitko ali po njej. Očitno je bilo bistvo paiana to, da je bil naslovljen na boga Paiana kot rešitelja. ${ }^{43}$ Pri Homerju pojejo paian grški bojevniki; prvič je pesem Apolonu, drugič izgleda kot zmagoslavna pesem, peta po zmagi.

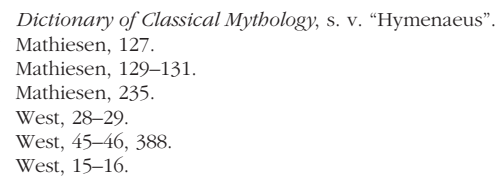


Zadnji glasbeni prizor Iliade je tren v sklopu Hektorjevega pokopa. Truplo trojanskega heroja položijo na ležišče; ob njem so aojdi, ki vodijo petje trena; vmes se s stokanjem oglašajo ženske. (XXIV, 719-722.) Tren, ki ga navaja Homer, ni le glasno žalovanje, pač pa petje; dejstvo, da ga vodijo aojdi, nakazuje, da je bilo petje trena poklicno opravilo. Celotna scena daje vtis daljšega obreda, katerega osrednji del je tren. Tudi iz kasnejšega časa so pogosta poročila o trenih, ${ }^{44}$ vendar so ohranjeni treni, Simonidovi in Pindarjevi, le fragmenti, ${ }^{45}$ zaradi česar je predstava o antični in homerski trenodiji zelo nepopolna. Homerjev opis daje vtis, da so se v trenu ob Hektorjevem truplu izmenjavali aojdi in ženske, ali pa da so se v petje aojdov občasno mešali ženski glasovi.

Še ena glasbena zvrst je nakazana v Iliadi: žensko petje oz. petje plesalk. Prvič ga srečamo v Olimpu, kjer na gostiji pojejo Muze, in sicer tako, da se izmenjujejo (I, 601-604). Drugič nastopi žensko petje, ko Homer opisuje poveljnike Ahilovih ladij in pove nekaj več tudi o Eudorosu: bil je sin Polymele in njegov oče se je zaljubil vanjo, ko jo je videl plesati v skupini pojočih in plešočih mladenk (XVI, 180-183). Izraz, ki ga na navedenem mestu uporablja Homer, sicer ni povsem jasen, vendar dopušča razlago, da plesalke hkrati tudi pojejo. Homerski svet je torej poznal podobo poklicnih ženskih pevk in plesalk.

Če se ob koncu pregleda homerskih glasbenih zvrsti ozremo po priložnostih, v katerih se pojavlja glasba, in njenih nosilcih, vidimo, da nastopa kot del sicer ne vsakodnevnih, vendar običajnih dogodkov življenja: poje se ob trgatvi, ob poroki, salpinks se oglaša sredi bitke, poje se ob zmagi, ob žrtvovanju, igranje je del pastirskega življenja, poje se ob pokopu; glasba je nepogrešljivi del gostije, v Iliadi sicer le gostije v Olimpu. Petje in igranje nastopata poleg tega skupaj s plesom, ne da bi bil ta po svoji vlogi vezan na drugi dogodek. Očitno je v homerskem svetu gibanje ob glasbi nekaj, kar more obstajati samo zase. Slednjič je glasba tudi čisto zasebno početje homerskih ljudi, namenjeno le lastnemu razvedrilu in veselju. Kot glasbenik samemu sebi nastopa v Iliadi le njen glavni junak, Ahil.

Kot pevci, igralci, plesalci nastopajo največkrat ljudje, ki so tudi sicer udeleženci prizora, katerega del je glasba: pastirji igrajo sirinks, vojščaki pojejo paian. Vendar se večkrat bolj ali manj ostro nakazuje delitev med tistimi, ki igrajo ali pojejo in predstavljajo žarišče glasbenega dogod$\mathrm{ka}$, in tistimi, ki imajo pri petju le stransko vlogo ali pa so udeleženi v njem le kot gledalci ali poslušalci. V prizoru trgatve poje in igra linos deček; ostali trgači tudi pojejo, vendar izhaja glasba iz dečka. Podobno poje himenaj v prizoru svatbe le ena skupina udeležencev, metdem ko ostali le gledajo in poslušajo. V bitki je trobljenje na salpinks delo posebnega vojščaka. Tudi skupina mladenk plesalk, med katerimi je Polymele, izgleda kot skupina, ki je bila posebej izurjena za svoje nastope. Delitev na muzike in nemuzike je prisotna tudi na Olimpu, kjer sta petje in igranje le opravilo Apolona in Muz. Vrhunec ima zgoščanje vloge glasbenika v homerskem aojdu. Aojd, poklicni pevec, ki se spremlja s formingo, je prisoten predvsem v Odiseji, vendar ga pozna tudi Iliada. Thamyris je aojd, človek, ki zna peti in igrati, in to je njegovo glavno življensko opravilo. Če ne bi bilo tako, se ne bi bahal s svojo umetnostjo, niti ga Muze ne bi mogle kaznovati s tem, da je svoje znanje pozabil. V prizoru s plesom na Ahilovem ščitu je sredi med plesalci aojd s svojo formingo in slednjič so v zaključni trenodiji prav aojdi voditelji glasbenega žalovanja.

\section{3}

Kot si je ob vživljanju v Homerjeve glasbene prizore možno ustvarjati predstavo o raznoliki zvočnosti, hkrati s tem pa tudi o razločno diferenciranih vlogah, ki jih je imela glasba v homer-

44 West, 23-24

45 Mathiesen, 134-135. 
ski družbi, tako omogoča pozorno branje Homerjevega besedila razmislek o tem, kako so homerski ljudje doživljali glasbo in kaj so videli v njej. Vsevedni pesnik sicer ne pove, kaj je glasba, niti ne pozna skupnega izraza zanjo, vendar se očitno zaveda, da je glasbena zvočnost nekaj drugega kot bodisi naravni bodisi po človeku povzročeni šumi in glasovi. Poleg tega nakazujejo nekatere njegove ubeseditve sicer komajda opazno, vendar pomembno ločnico med plesom in gibanjem ter med glasbo in zvokom. Najobširnejši plesni prizor Iliade je umetniško upodobljen na Ahilovem ščitu (XVIII, 590-606). Opis tega prizora ni bogat le z zanimivimi podrobnostmi, ampak tudi z izrazi, ki poudarjajo njegovo lepoto: Hefajst je "umetniško« izdelal plesišče, podobno tistemu, ki ga je naredil Dedal "lepolasi“ Ariadni; na njem plešejo mladeniči in mladenke, "vredne mnogih govedi" (prinesenih kot darilo pri snubljenju); one imajo "lična" ogrinjala iz "finega platna", oni "lepo spredene" plašče, ki se "svetijo" od olja; one nosijo "lepe" vence, oni "zlate" meče na "srebrnih" jermenih; zdaj "lahkotno" tečejo z "izurjenimi" nogami v eno smer (okroglega plesišča), podobno, pravi pesnik, kot ko sedeči lončar drži v rokah lončarsko vreteno in preizkuša, ali bo teklo. Potem se plesno gibanje obrne. Plesno gibanje, očitno krožno, je tu primerjano s tekom lončarskega vretena, kar nakazuje povezavo med obema gibanjema. Če se vprašamo po pomenskem razločku med njima, je očitno, da je gibanje lončarskega vretena zgolj v funkciji določenega delovnega postopka, zgolj posledica opravila, katerega končni smisel je lončarski izdelek. Drugače je s plesom: tudi to gibanje je krožno gibanje, vendar nima nobenega smisla zunaj sebe. Tako bi bilo ples mogoče videti kot zavestno abstrakcijo v življenju posledično prisotnega gibanja, abstrakcijo, ki je sama sebi namen.

Podobno ločnico, tokrat med neglasbenim in glasbenim zvokom, je mogoče razbrati v prizoru, ko se Ahil prvič pokaže Trojancem. Ahil zarjove, kot bi vrisnil salpinks (XVIII, 202-221). Čeprav primerja Homer Ahilov glas s salpinksom, kar bi lahko pomenilo, da Ahil posnema salpinks, je treba primero smiselno razumeti v obrnjenem redu: glasbilo posnema človeški bojni krik in v tem smislu je instrumentalna abstrakcija človeškega glasu; abstrakcija, ki sicer ni sama sebi namen, saj ima podobno funkcijo kot bojni krik, vendar ni več naravni glas, pač pa umetno povzročeni trobljaj na glasbilu. Z drugimi besedami se v Homerjevi primeri glasbeno neartikulirani človeški glas oz. krik ob prenosu na umetno narejeno glasbilo preoblikuje in na neki način prisiljeno uresniči prek zvokov trobila; to pa pomeni prek glasbeno artikuliranih tonov alikvotne vrste, ki so obveljali za najosnovnejše gradivo glasbe nekaj naslednjih tisočletij. Čeprav ima glas salpinksa v Homerjevi primeri določeno funkcijo, je glasba. Po svoji zvočnosti je nekaj, kar v naravi samo po sebi ne obstoji; poleg tega ima svojo vsebino in svoj učinek. Ta vsebina ni le znak v smislu dogovorjenega simbola za začetek bitke. Iz celotne scene veje vzdušje, da ima glas salpinksa (omenjen sicer le kot primera) še neko drugo težko razložljivo vsebino z zelo močnim učinkom; ta vsebina je lahko le vsebina tonov zaigranega trobljaja in kot taka je nujno glasbena vsebina. To pomeni: v homerskem svetu je skrito prisotna misel, da je glasba prečiščena abstrakcija naravnih zvokov s svojo lastno vsebino.

Trobljaj salpinksa razločno kaže razkorak med glasbenim in neglasbenim; lahko ga razumemo kot eksemplarični primer izvora ali začetka glasbe, o čemer je rada razpravljala na mitologijo oprta antična in srednjeveška glasbena teorija. Kaj je glasba v primeri z drugimi zvoki, je v homerskem svetu razvidno sicer le iz njenega najbolj prvobitnega primera, kot ga predstavlja glas salpinksa, glasbila, ki v antiki ni doseglo visokega statusa drugih muzičnih instrumentov. Zveza med naravnim človeškim krikom in salpinksom je še razvidna, med urejenimi glasovi forminge in naravnimi zvoki pa ni več prepoznavna. Med glasom salpinksa in igranjem homerske forminge so pretekla najbrž stoletja razvoja, in tako se zdi, da je že v samem homerskem svetu glasba prepotovala tako dolgo pot, da je bil njen začetek komaj še prepoznaven.

Dolga zgodovinska pot od glasbe, kot jo predstavlja salpinks, do glasbe, kot jo je premogla forminga, je razvidna tudi iz tega, da sta igranje, zlasti na formingo, in petje v homerskem svetu po eni strani dar, po drugi pa dejavnost, ki zahteva znanje. Aojd Thamyris ne bi mogel tako tragično pozabiti igran- 
ja na kitharis, če ne bi bilo to znanje; Muze mu ne bi mogle odvzeti božansko vzvišenega petja, če mu ga poprej ne bi dale (II, 599-600). Polydamas pravi Hektorju, da je bog nekomu dal zmožnost plesa, drugemu zmožnost igranja na kitharis in petje (XIII, 730-731). V podobnem smislu je naveden pridevnik, s katerim je označen aojd v plesnem prizoru na Ahilovem ščitu, pridevnik božanski (XVIII, 604). Vse to kaže, da je bila glasba v homerskem svetu razločno razpoznavna dejavnost.

Samo petje in igranje je v Iliadi največkrat razumljeno kot lepo ali sladko in metonimično so lepi tudi ljudje, ki pojejo ali igrajo, kot so lepa tudi sama glasbila. Apolon igra na prelepo formingo (I, 603); Ahilova forminga je lepo izdelana in ima srebrno prečko (IX, 187); kitharis je omenjena skupaj z darovi Afrodite, ki naj bi jih imel Paris (III, 54); spanec, ljubezen, sladka pesem in ples so na drugem mestu našteti v isti sapi (XIII, 636-637); Polymele je lepa v plesu med pojočimi mladenkami (XVI, 180); deček, ki poje linos, poje lepo, z nežnim, milim glasom; ljubko igra na glasno formingo (XVIII, 569-571). Težko je reči, kaj pomenijo Homerjevi pridevniki in še zlasti, kaj mu je pomenilo "lepo«; vsekakor pa je očitno, da so homerski ljudje doživljali lepo in da so kot lepo doživljali tudi glasbo. Doživljanje glasbe pa ima v homerskem svetu tudi razločne učinke. Ahil si z igranjem in petjem razveseljuje in vedri duha, svojo notranjost (IX, 186-188); pastirca se razveseljujeta s piskanjem na sirinks (XVIII, 525-526); ljudem, ki opazujejo plesni prizor s formingo, je to v razvedrilo (XVIII, 603-604). Čeprav je težko s stališča današnjega pojmovanja natančneje določiti, kaj pomenijo Homerjevi glagoli in deležniki, je razvidno, da ima glasba, se pravi prečiščena abstrakcija zvokov z lastno vsebino, na homerske ljudi in na njihove duševnosti prepoznaven učinek.

Glasbeni prizori v Iliadi

\begin{tabular}{|c|c|c|c|}
\hline Mesto & Pevci: zvrst & Igralci: glasbilo & Plesalci \\
\hline $\mathrm{I}, 1$ & boginja (Muza) & & \\
\hline I, 470-474 & Grki: paian & & \\
\hline I, 601-604 & Muze & Apolon: forminga & \\
\hline II, 594-600 & Thamyris (aojd) & Thamyris: kitharis & \\
\hline II, 594-600 & Muze & & \\
\hline III, 54 & & Paris: kitharis & \\
\hline III, 392-394 & & & Paris \\
\hline VI, 358 & prihodnji rodovi & & \\
\hline IX, 185-189 & Ahil & Ahil: forminga & \\
\hline $\mathrm{X}, 11-13$ & & Trojanci: avlos, sirinks & \\
\hline XIII, 636-637 & (neimenovani) & & (neimenovani) \\
\hline XIII, 731 & (neimenovani) & (neimenovani:) kitharis & (neimenovani) \\
\hline $\mathrm{XV}, 508$ & & & Trojanci \\
\hline XVI, 180-183 & Polymele in mladenke & & Polymele in mladenke \\
\hline XVI, 617 & & & Meriones \\
\hline XVIII, 219-221 & & oblegovalci: salpinks & \\
\hline XVIII, 491-496 & (neimenovani:) himenaj & $\begin{array}{l}\text { (neimenovani:) } \\
\text { avlos, forminga }\end{array}$ & mladeniči \\
\hline XVIII, 525-526 & & pastirji: sirinks & \\
\hline XVIII, 569-572 & deček, mladeniči, mladenke: linos & deček: forminga & mladeniči, mladenke \\
\hline XVIII, 590-606 & & aojd: forminga & $\begin{array}{l}\text { mladeniči, } \\
\text { mladenke, voditelja }\end{array}$ \\
\hline XXII, 391 & Grki: paian & & \\
\hline XXIV, 62-63 & & Apolon: forminga & \\
\hline
\end{tabular}




\section{SUMMARY}

Music is quite frequently mentioned in The Iliad and there are descriptions of several specific events in which music is an essential part of the scene. References to singing, playing and dancing (listed in the table) may be considered from three different aspects. Firstly, they include expressions that can be interpreted as technical descriptions of the music played or sung, especially if compared to other iconographical and literary sources. Besides singing (men's, maidens', mixed, with or without instruments, bard's singing to the phorminx), Homer mentions five instruments: the phormin al music, there is the playing of the phorminx (alone or accompanying dance), the sounds of the salpinx (as war music), the playing of syringes as the music of the pastoral world, and the playing of syringes and auloi as an element of revel. Thirdly, Homer's descriptions and vocabulary reveal the aesthetic impact of the music. The characters in The Iliad experience the beautiful (whatever this might have implied) and among the things considered beautiful we also find music. An interesting clue as to the very nature of music can be found in the text: the sound of the salpinx, although mentioned only metaphorically, functions in the epic as an imitation of the war cry. It cannot escape notice, however, that this must have been realised through a series of harmonics, i.e., through the most raw material of music. In Homer's imagination, music thus appears to be a specific abstraction of natural sounds with its own content, a necessarily musical content. 